\title{
ANÁLISE CRÍTICA DO DISCURSO MULTIMODAL DE REPRESENTAÇÕES DE PROFESSORES/AS EM CAPAS DE REVISTAS NACIONAIS
}

\author{
Critical Discourse Analysis of Representations of Teachers on \\ National Magazine Covers
}

\author{
Fábio Alexandre Silva BEZERRA \\ Universidade Federal da Paraíba \\ fabes10@yahoo.com.br \\ https://orcid.org/0000-0002-3383-0188 \\ Tammara Thaís de Sousa OLIVEIRA \\ Universidade Federal da Paraíba \\ tammara.oliveira@hotmail.com \\ https://orcid.org/0000-0002-5089-8176
}

\begin{abstract}
RESUMO: Este artigo apresenta resultados de pesquisa sobre representações imagéticas e verbais de professores/as em capas das revistas Veja, Carta Capital e Nova Escola a partir de conceitos e categorias de análise da gramática do design visual (GDV) de Kress e van Leeuwen (2006) e da Análise Crítica do Discurso (ACD) de Fairclough (1992; 2015[1985]). O objetivo principal é analisar as representações construídas sobre professores/as e revelar os sentidos produzidos, além de evidenciar discursos dominantes e marginais presentes nas publicações. A análise multimodal revelou que as representações dos/as professores/as na capa e na matéria da revista Veja estão voltadas para uma tentativa de responsabilizar principalmente esses/as profissionais pelo fracasso ou sucesso dos/as alunos/as. Em contrapartida, as revistas Carta Capital e Nova Escola tratam a temática expondo a desvalorização dessa profissão e os principais problemas enfrentados pelos/as professores/as brasileiros/as. Dessa forma, os resultados sugerem que as publicações se mostraram comprometidas com suas linhas editoriais, utilizando recursos semióticos que revelaram os posicionamentos ideológicos em seus discursos. PALAVRAS-CHAVE: Análise Crítica do Discurso; Multimodalidade; Mídia; Professores/as.
\end{abstract}

ABSTRACT: This paper presents results of research about visual and verbal representations of teachers on the covers of magazines Veja, Carta Capital, and Nova Escola based on concepts and categories of analysis

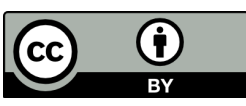


from the grammar of visual design (GVD) by Kress and van Leeuwen (2006) and Critical Discourse Analysis (CDA) by Fairclough (1992; 2015 [1985]). The main objective is to analyze the representations construed about teachers and to unveil the meanings created, in addition to showing dominant and marginal discourses in these publications. The multimodal analysis revealed, on the one hand, that the representations of teachers on the cover and in the report of Veja seek to hold mainly these professionals responsible for the students' failure or success. On the other hand, the magazines Carta Capital and Nova Escola deal with the theme exposing the devaluation of this profession and the main problems faced by Brazilian teachers. Thus, the results suggest that the publications were committed to their editorial lines, using semiotic resources that revealed the ideological positioning underscoring their discourses. KEYWORDS: Critical Discourse Analysis; Multimodality; Media; Teachers.

Seria na verdade uma atitude ingênua esperar que as classes dominantes desenvolvessem uma forma de educação que proporcionasse às classes dominadas perceber as injustiças sociais de maneira crítica

Paulo Freire (1984, p. 89)

\section{INTRODUÇÃO}

Nas últimas décadas, surgiram mudanças significativas na maneira como os textos são produzidos, distribuídos e consumidos, de modo que os tradicionais textos escritos têm sido cada vez mais substituídos pelos multimodais, que apresentam dois ou mais modos semióticos em sua composição (p. ex.: palavras e imagens). Notícias, campanhas publicitárias, instruções de uso, e artigos científicos, são apenas alguns exemplos de gêneros que produzem múltiplos significados ao mobilizarem variados recursos semióticos (VAN LEEUWEN, 2005).

Do mesmo modo, as capas de revista, objeto de análises neste artigo, são textos multimodais que, ao combinar os códigos visual e verbal, "contribuem, por exemplo, para a manutenção ou mudança de padrões estabelecidos de comportamento e de visões de mundo na sociedade em que circulam" (BEZERRA; ROCHA, 2020, p. 216). Percebe-se, portanto, que, à medida que essas novas práticas de comunicação multimodais ganham mais espaço, torna-se imprescindível o desenvolvimento do que Royce (2007) denomina Revista X, v. 16, n. 3, p. 742-772, 2021. 
de competência comunicativa multimodal, sendo compreendida como "o conhecimento e o uso da linguagem no que diz respeito às dimensões visual, gestual, auditiva e espacial da comunicação, incluindo aquelas mediadas pelo computador” (HEBERLE, 2010, p. 102), para que possamos, cada vez mais, ler o mundo de maneira crítica, capacidade destacada por Freire (1984), na epígrafe deste artigo, como essencial para a superação de relações de opressão.

Para tanto, são necessárias ações que localizem o trabalho com a leitura e a produção de textos multimodais como centrais na sociedade contemporânea, mais especificamente nos contextos educacionais formais e/ou não formais visando ao desenvolvimento de experiências significativas para os/as aprendizes "a partir da atenção docente ao avanço tecnológico e seu consequente impacto nas interações sociais e no processo de ensino-aprendizagem" (BEZERRA, 2016, p. 197).

É possível afirmar que a competência comunicativa multimodal é ainda mais necessária quando nos deparamos com textos midiáticos. Para Kellner (2003), a mídia conta com novas tecnologias de comunicação capazes de libertar ou dominar, manipular ou esclarecer. Sendo assim, os indivíduos precisam desenvolver uma formação leitora crítica que lhes permitirá viver em sociedade de maneira mais consciente e proativa ao serem capazes de questionar criticamente os diferentes tipos de textos, assim como reconhecer os recursos de sentidos mobilizados. Ademais, quando consideramos o papel da mídia, notamos que os meios de comunicação dominantes têm o poder de influenciar o seu público quanto ao modo de agir e pensar.

Em outras palavras, as mídias dispõem de recursos capazes de interferir nas crenças, nos desejos e nas opiniões daqueles/as que as consomem (KELLNER, 2003). A leitura crítica do texto multimodal pode, por conseguinte, revelar como algumas representações midiáticas acabam favorecendo determinados/as atores/as sociais em detrimento de outros/as. Este processo ocorre especialmente quando as publicações se utilizam de manobras editoriais e textuais estratégicas para direcionar sua mensagem com o intuito de incentivar determinados comportamentos e crenças no público-alvo, fazendo com que este passe a enxergar e avaliar questões particulares por suas lentes e seus vieses ideológicos.

No caso dos textos multimodais nas capas das publicações analisadas neste artigo, argumentamos, inicialmente, que as representações imagéticas e verbais acerca dos/as professores/as presentes em tais veículos midiáticos podem construir imagens e provocar concepções particulares a respeito desses/as profissionais. Por conseguinte, evidencia-se a importância de desenvolver pesquisas que explorem o potencial semiótico de construção 
de representações nos textos multimodais, além de projetos de multiletramentos, como propostos pelo Grupo de Nova Londres (NLG, 2000[1996]), mais recentemente atualizados por Cope e Kalantzis (2015), para otimizar a competência comunicativa multimodal a partir de práticas educativas que evidenciem as multiplicidades semiótica e cultural (NASCIMENTO; BEZERRA; HEBERLE, 2011; ROJO, 2012).

Nesse contexto, portanto, o objetivo geral desta pesquisa é analisar como as capas das revistas criam representações dos/as professores/as no contexto nacional. Como desdobramentos, os objetivos específicos são: 1) descrever as representações construídas sobre professores/as nas capas de revistas com base nos elementos textuais e imagéticos; 2) desvendar sentidos construídos por meio desses recursos multimodais para compreender discursos dominantes e periféricos produzidos pelas representações, revelando e problematizando um imaginário coletivo no que tange a figura do/a professor/a, suas identidades e seus contextos de atuação na sociedade contemporânea; e 3) revelar a curva ideológica informada pela política editorial das publicações analisadas, a partir da correlação entre as capas analisadas e as leituras das matérias correspondentes, visto que a análise de elementos micro estruturais (i.e., gramática, vocabulário e coesão) também deve ser reforçada pela inclusão de considerações da macroestrutura (i.e., práticas discursivas e práticas sociais, em termos de ideologias, relações de poder e questões de diversidade) em que tais textos se inserem.

Sendo assim, esta investigação se pauta em conceitos e categorias de análise de estudos de multimodalidade, da Análise Crítica do Discurso e do letramento crítico da mídia, que serão descritos nas sessões seguintes.

\section{MULTIMODALIDADE: A GRAMÁTICA DO DESIGN VISUAL}

Ao tratar do texto multimodal, Kress e van Leeuwen (2006) afirmam que as estruturas visuais se assemelham às estruturas linguísticas, constituindo formas de interação social, de modo que as escolhas de representação, de interações e de composição de uma imagem também são feitas a partir de uma rede maior de potenciais significados.

Com isso, surge a necessidade de letramentos visuais, pois tanto o texto verbal quanto o visual criam relações de poder, constroem identidades e difundem ideologias. Em face dessa necessidade, Kress e van Leeuwen apresentam sua gramática do design visual (GDV), que serve de base para estudos linguísticos relacionados à leitura crítica de imagens e à compreensão do seu processo de construção de sentidos a partir da mobilização de recursos semióticos específicos em face de seus potenciais de sentido também particulares. 
A partir da GDV, é possível verificar os diferentes modos de representação de um texto multimodal, ou seja, os significados representacionais, os interacionais e os composicionais que operam simultaneamente em toda a arquitetura multimodal. Os significados representacionais correspondem às representações das experiências, sendo organizados em dois campos ideacionais principais: representações narrativas e conceituais.

As representações narrativas são realizadas por meio de processos que inserem os/as participantes em eventos e ações, quais sejam: acional, reacional, mental, e verbal. Os processos acional e reacional são identificados pela presença de um vetor (linha imaginária indicando ação/movimento e/ou direção). No processo reacional, o vetor é formado necessariamente pelo olhar do/a participante representado/a.

Os processos acionais e reacionais podem, ainda, ser transacionais (Fig. $1^{1}$, pois podemos ver quem age e quem é objeto da ação - neste caso, a menina segura a bola) ou não transacional (Fig. 2, pois não podemos ver, por exemplo, para o que/quem o participante está olhando, i.e. reagindo).

Figura 1: Processo acional transacional.

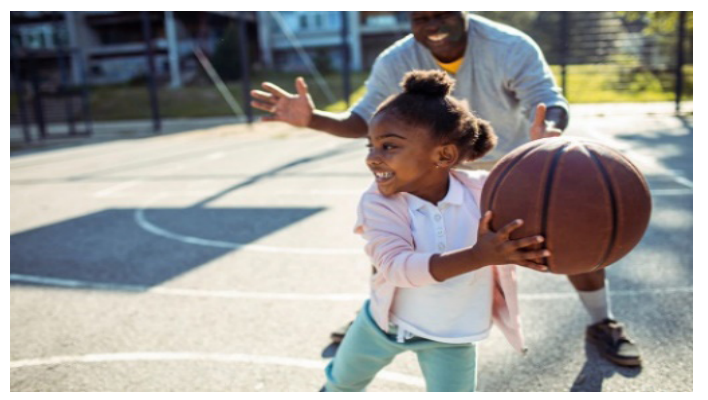

Fonte: Pixabay.
Figura 2: Processo reacional não transacional.

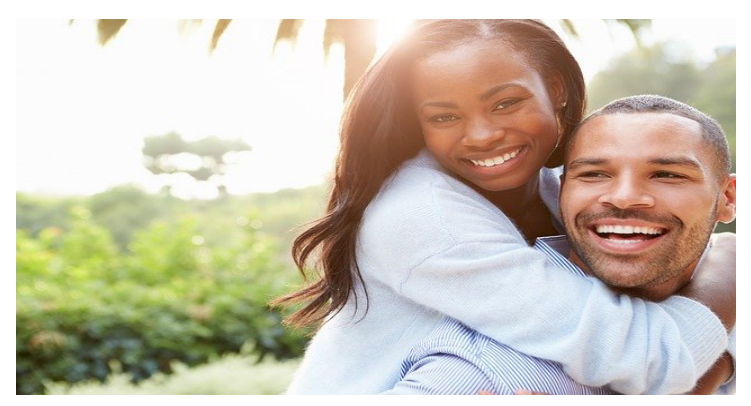

Fonte: Pixabay.

A Figura 3, por sua vez, exemplifica uma reação transacional em que uma menina olha a outra, caracterizando, ademais, elemento de unilateralidade, pois só uma (reator) está olhando a outra (fenômeno). Já na Figura 4, observamos múltiplos processos de reação não transacionais uma vez que não conseguimos saber para onde os meninos (i.e., reatores) estão olhando. Como mencionado, também há processos mentais e verbais

\footnotetext{
${ }^{1}$ Todas as imagens utilizadas nesta seção para ilustrar as categorias de análise da gramática do design visual de Kress e van Leeuwen (2006) foram retiradas de páginas da internet que trazem imagens de domínio público.
} 
(Fig. 5), sendo aqueles marcados pela presença de balões de pensamento, enquanto estes são realizados por balões de fala.

Figura 3: Processo reacional transacional. Figura 4: Processos reacionais não transacionais.

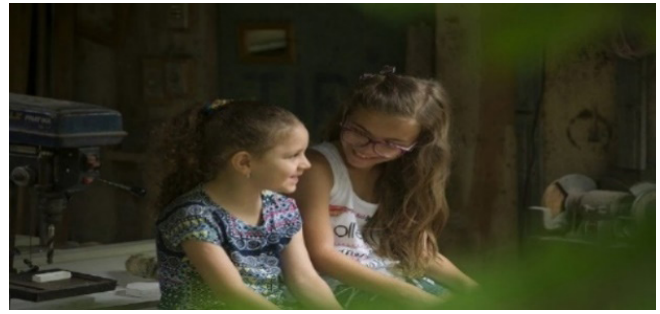

Fonte: Pixabay.

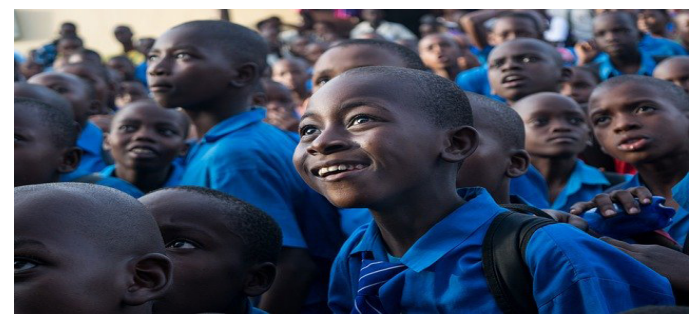

Fonte: Pixabay.

Figura 5: Processos verbais e processo mental.
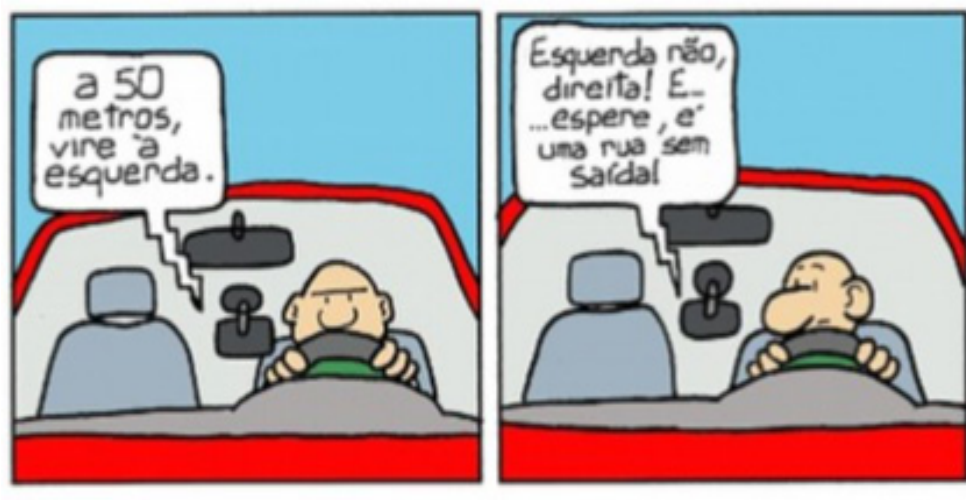

Fonte: Flickr.

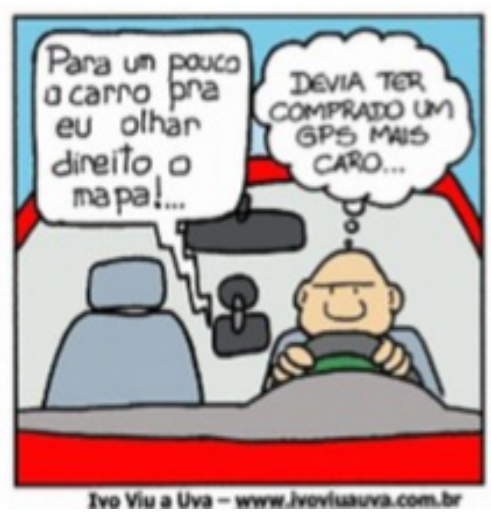

Quanto às representações conceituais, estas se referem a descrições e classificações. Assim sendo, elas possuem como características principais a ausência de vetores e menor detalhamento (ou mesmo ausência) de pano de fundo, sendo representadas a partir de escolhas nos seguintes sistemas: organização dos/as participantes envolvidos/ as em taxonomias explícitas ou implícitas (processos classificacionais, como na Fig. 6); ilustração de relações parte/todo (processos analíticos, como na Fig. 7); e presença de elementos atribuindo ou sugerindo valores simbólicos ao texto multimodal (processos simbólicos, como na Fig. 8). 
Figura 6: Processo classificacional implícito.

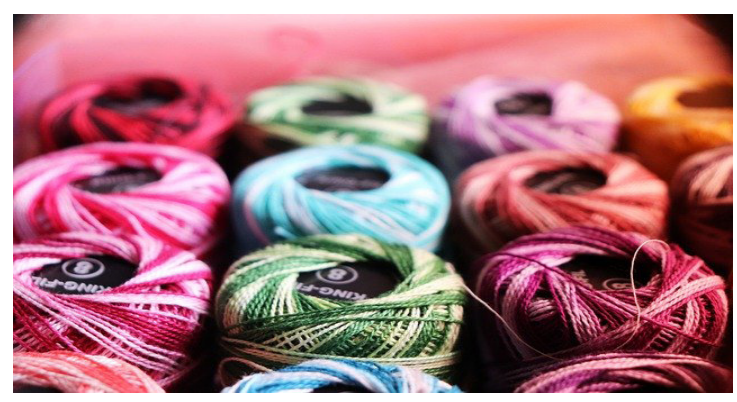

Fonte: Pixabay.
Figura 7: Processo analítico.

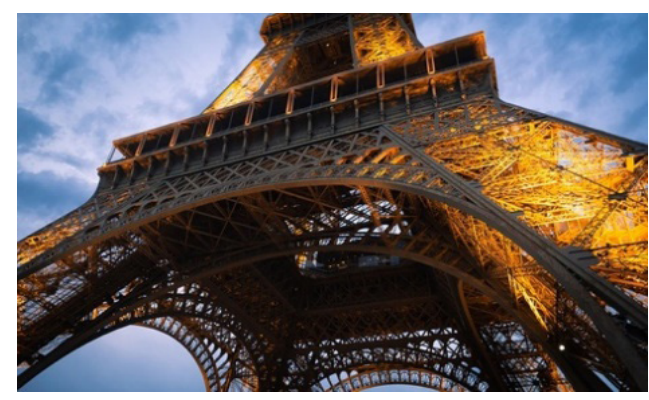

Fonte: Pixabay.

Figura 8: Processo simbólico sugestivo.

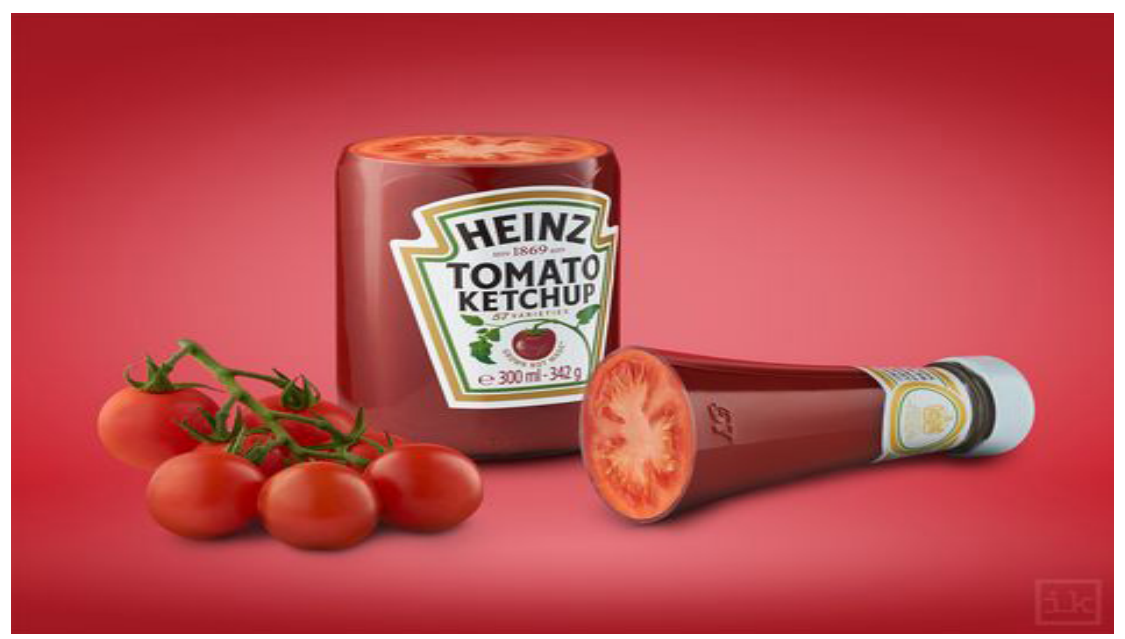

Fonte: Pinterest.

A metafunção interacional, por sua vez, possui quatro componentes, quais sejam: contato (podendo ser de demanda, se o olhar do/a participante representado/a estiver voltado para o/a leitor/a; ou de oferta, se o olhar não estiver focado no/a leitor/a); distância social (íntimo, por plano fechado da imagem; social, por plano médio; ou impessoal, por plano aberto); atitude (variando de acordo com o ângulo em que o/a participante é representado: se frontal, há envolvimento; se oblíquo, distanciamento); poder (se for alto o ângulo da câmera, há poder do/a leitor/a; se for no nível do olhar, há igualdade entre leitor/a e participante representado/a; se for baixo, há poder do/a participante representado/a). Na Figura 9, exemplificamos as categorias categoria e distância social, ao passo que atitude e poder estão ilustrados na Figura 10. 
Figura 9: Demanda e intimidade.

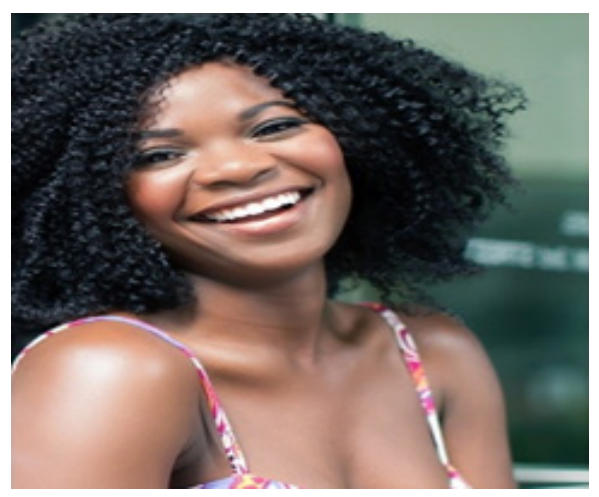

Fonte: Pixabay.
Figura 10: Distanciamento e igualdade.

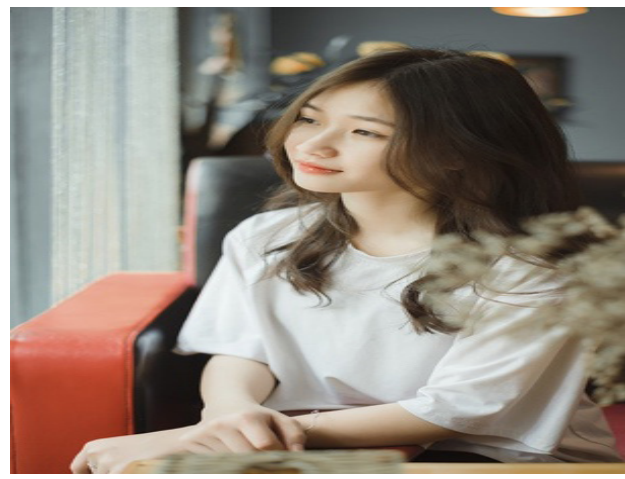

Fonte: Pixabay.

Por fim, os significados composicionais tratam da organização dos elementos imagéticos no texto multimodal a partir da utilização de recursos visuais em três aspectos distintos: valor da informação, enquadramento, e saliência. O valor da informação referese à posição dos elementos na composição da imagem nas seguintes relações: dado/novo (Fig. 11), em que as informações já conhecidas pelo/a leitor/a (dado) se localizam à esquerda, e as informações novas (novo) à direita; ideal/real (Fig. 12), em que, na parte superior, aparece a sugestão ou promessa de algo ideal, que deve ser alcançado/desejado, ao passo que, no campo inferior, vêm informações ligadas ao concreto/real; por fim, a relação centro/margem, segundo a qual as informações centrais são mais relevantes que as marginais.

Figura 11: Relação dado/novo e enquadramento. Figura 12: Relação ideal/real e saliência.

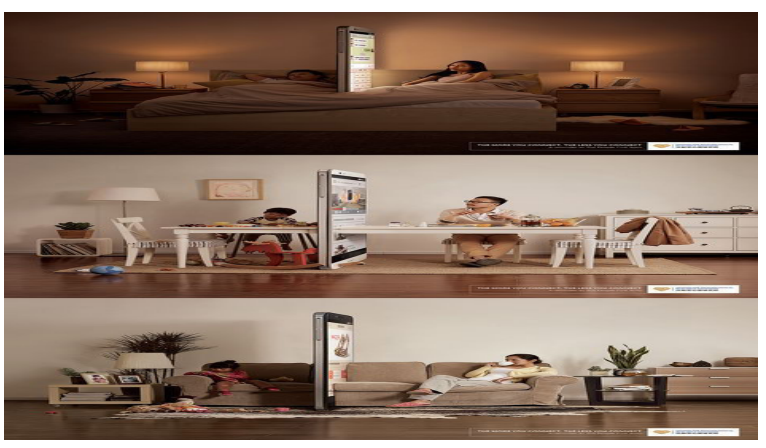

Fonte: Pinterest.

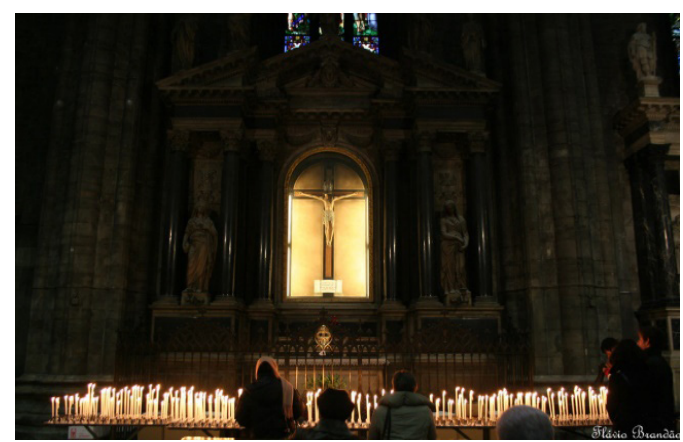

Fonte: Flickr. 
O enquadramento é atingido por meio (da ausência) de molduras que (des) conectam os elementos imagéticos. Quando os elementos que compõem a imagem estão enquadrados, dizemos que eles estão menos conectados (Fig. 11); quando não enquadrados (Fig. 8), estão mais conectados. Por fim, a saliência é utilizada como recurso para atrair a atenção do/a leitor/a por meio do uso de tamanho relativo, cor, contraste em luz e sombra (Fig. 12), e posicionamento em primeiro ou segundo plano.

\section{ANÁLISE CRÍTICA DO DISCURSO: MODELO TRIDIMENSIONAL DE FAIRCLOUGH}

Descrevendo a perspectiva de Análise Crítica do Discurso (ACD) proposta por Fairclough (1992; 2015[1989]) em seu modelo tridimensional, Meurer (2005) explica que, para fazer a análise crítica de um texto, devemos articular o evento discursivo (texto) com suas respectivas práticas discursivas em articulação com as práticas sociais nas quais se insere (Fig. 13).

$\mathrm{Na}$ dimensão mais interna, é no texto (evento discursivo) onde encontramos a descrição linguística. Este é o nível de análise que mais se aproxima do significado literal do texto, sendo descrito a partir de marcas do léxico, de estruturas da gramática, de aspectos de coesão, e de seus elementos estruturais mais evidentes.

Quanto às práticas discursivas, o evento discursivo é interpretado levando-se em considerações as esferas de produção, de distribuição e de consumo do texto em análise, para que seja possível articular, em um nível mais intermediário de profundidade do texto, essas informações com sentidos produzidos em face de características das forças dos atos de fala presentes, das relações de coerência estabelecidas, bem como da maneira como o texto se relaciona com outros textos e com outros discursos.

$\mathrm{Na}$ dimensão mais ampla, ao se analisar um evento discursivo a partir das práticas sociais, procura-se revelar e discutir marcas ideológicas, relações de poder e posturas hegemônicas que o permeiam. Constata-se, dessa maneira, a evidente necessidade de considerarmos questões que vão além do nível textual quando queremos discutir ideologias, discursos e relações de poder construídos pela mídia. 
Figura 13: Modelo tridimensional de Fairclough.

PRÁTICAS SOCIAIS (o que as pessoas fazem)

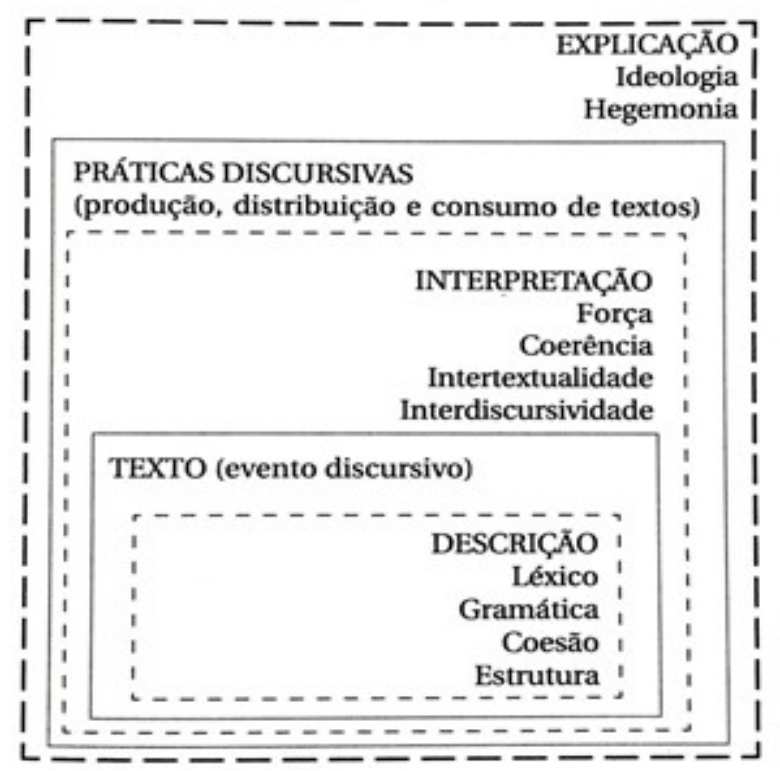

Fonte: Meurer (2005, p. 95).

Em outras palavras, com base nos dados obtidos pela análise multimodal do texto, também deve haver a discussão das práticas discursivas que esse mesmo texto produz, bem como das implicações ideológicas, das relações de poder e das identidades estabelecidas por meio das práticas sociais nas quais ele se insere.

\section{PROCEDIMENTOS METODOLÓGICOS}

Inicialmente, as capas foram selecionadas por meio de uma simples busca pelos termos "professores", "professoras" e "capas de revistas" no Google Imagens. Dentre os resultados mostrados, foram selecionadas, primeiramente, seis capas, de modo que houvesse equilíbrio entre o número de exemplares de cada publicação ( 2 da Veja, 2 da Carta Capital e 2 da Nova Escola). Contudo, tendo em vista o escopo mais limitado desta pesquisa, por questões de tempo e espaço, a amostra selecionada foi reduzida para as 
três capas analisadas neste artigo ${ }^{2}$. Como indicado, priorizamos publicações de grande tiragem e com destaque significativo no setor editorial. As duas primeiras capas são das revistas Veja (edição 2074, de 20 de agosto de 2008) e Carta Capital (edição n 1055, de 22 maio de 2019), que estão entre os semanários mais lidos do país, entre seu público marcadamente diverso, segundo o Instituto Verificador de Circulação (IVC, 2019), ao passo que a terceira capa é da revista Nova Escola (edição 318, de janeiro de 2019), publicação consolidada entre o público docente com mais de 30 anos de história.

De início, cada capa foi analisada individualmente, partindo da análise multimodal que buscou enfatizar os sentidos construídos pela linguagem verbal e pelas imagens em sua inter-relação. Para tal, foram analisados os sentidos representacionais, com vistas à descrição das representações narrativas e/ou conceituais, observando-se quais processos foram construídos por meios dos recursos imagéticos. Depois, tendo por base a função interacional, investigaram-se as relações entre os/as participantes representados/as (PR) e o/a leitor/a por meio dos elementos: contato; distância social; atitude e poder. Por fim, as capas foram analisadas com base nos significados composicionais, abrangendo a organização dos elementos imagéticos a por meio da utilização de recursos visuais em três aspectos distintos: valor da informação, enquadramento e saliência.

Após tal análise multimodal, no nível textual, segundo o modelo tridimensional de Fairclough, realizou-se a análise fundamentada na ACD a partir da leitura das reportagens correspondentes às capas com o intuito de averiguar os elementos textuais que serviam de sustentação à análise imagética, começando pelas práticas discursivas nas quais os textos se inserem, dando destaque para questões de produção, distribuição e consumo.

Posto isso, levou-se em consideração o discurso da mídia e a relevância do seu papel na sociedade, enquanto as práticas sociais constitutivas dos textos em análise foram discutidas. Nesse momento, reforçou-se a importância do desenvolvimento da leitura crítica dos textos midiáticos, tendo em vista a necessidade de desvelar e questionar os discursos dominantes que perpassam tais textos.

\footnotetext{
${ }^{2}$ Tendo obtido autorização expressa das revistas Carta Capital (Fig. 15) e Nova Escola (Fig. 16), não recebemos retorno do setor responsável da revista Veja quanto a nossa solicitação para uso da capa analisada neste artigo. No entanto, considerando o disposto na Lei $n^{\circ} 9.610$ (BRASIL, 1998), sabemos que é permitida "a reprodução, em quaisquer obras, de pequenos trechos de obras preexistentes, de qualquer natureza, ou de obra integral, quando de artes plásticas, sempre que a reprodução em si não seja o objetivo principal da obra nova e que não prejudique a exploração normal da obra reproduzida nem cause um prejuízo injustificado aos legítimos interesses dos autores" (Art. 46, VIII). Gostaríamos, não obstante, de reconhecer a editora Abril como detentora dos direitos autorais da capa analisada neste artigo (Fig. 14), publicado em periódico nacional de acesso gratuito, sem quaisquer fins lucrativos, com o objetivo de compartilhamento de resultados de pesquisa científica conduzida em universidade pública nacional.
} 


\section{ANÁLISE DOS DADOS: RESULTADOS E DISCUSSÃO}

Nesta seção, são apresentadas as análises com base em conceitos teóricos e categorias de análise propostos por Kress e van Leeuwen (2006). Em seguida, são utilizados conceitos propostos pela ACD (FAIRCLOUGH, 1992; 2015[1989]) com a finalidade de desvendar os sentidos construídos pelas imagens assim como discorrer sobre as implicações discursivas de tais representações em textos midiáticos.

\section{Revista Veja}

No âmbito da análise das representações no nível das práticas discursivas, é necessário destacar que a revista Veja, lançada em 1968, pela Editora Abril, pelos jornalistas Victor Civita e Mino Carta, é a revista de maior circulação no mercado editorial brasileiro. Segundo o mídia kit disponível no site do grupo Abril: "são 800 mil exemplares em circulação toda semana, sendo a maior entre as semanais de informação do Brasil e a segunda maior no mundo, alcançando toda semana mais de 6 milhões de leitores/as no impresso e no digital". ${ }^{3}$ Além das versões impressa e digital, a revista chega ao público através de podcasts disponíveis em plataformas de áudio, como Spotify, Deezer e iTunes. De acordo com dados disponíveis no portal de publicidade da marca, o maior grupo consumidor da revista atualmente é formado por pertencentes das classes A, $\mathrm{B}$ e $\mathrm{C}$, em sua maioria homens com idade acima de 50 anos.

Na capa em análise (Fig. 14), vemos um menino escrevendo em quadro escolar a giz a frase "O inssino no Brasiu è otimo" ( $\mathrm{O}$ ensino no Brasil é ótimo) com vários erros de ortografia. Logo abaixo do quadro, lê-se a frase "Os erros não são só dele. Os estudantes brasileiros são os piores nos rankings internacionais, mas... mais de $90 \%$ dos professores e pais aprovam as escolas". Ao analisar as representações da capa, identificamos, primeiramente, uma narrativa por meio de um processo de ação transacional, pois podemos identificar uma ação sendo realizada por um ator (menino) em relação a uma meta definida (a frase), em uma circunstância também específica (no quadro escolar, na sala de aula). Nesse caso, o evento no qual o participante representado está inserido é a ação de escrever a frase, ação esta que é identificada pelo vetor formado pelo braço do menino e pelo giz, junto à imagem sendo escrita no quadro.

\footnotetext{
${ }^{3}$ PUBLIABRIL. Marcas e plataformas: Veja. Disponível em: http://publiabril.abril.com.br/ marcas/veja. Acesso em: 01 abr. 2020.
}

Revista X, v. 16, n. 3, p. 742-772, 2021. 
Sobre as representações conceituais, podemos destacar um processo simbólico formado pelas cores utilizadas na capa, que nos remete às cores da bandeira do Brasil. A combinação do verde do quadro, os tons de amarelo da logo da revista e da medalha, juntamente com o branco do giz, mais o azul da camiseta do menino pode simbolizar o conteúdo desta matéria da revista. Vale mencionar que as duas únicas chamadas de matérias mostradas na capa também têm relação com o contexto nacional. Note que, apesar de serem matérias distintas, a chamada secundária (o nadador César Cielo comemorando sua medalha de ouro), posicionada acima da chamada principal, também estabelece relação com a imagem do país no contexto internacional.

Figura 14: Capa da Revista Veja (ed. 2074 de 2008).

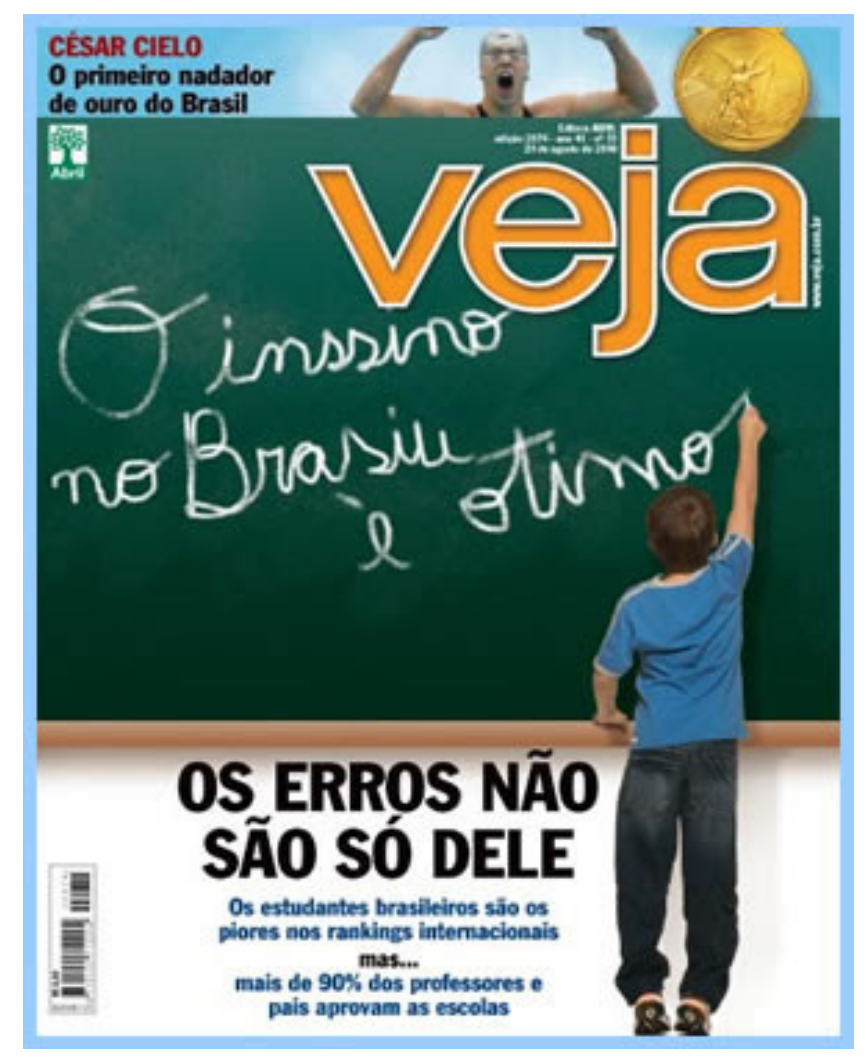

Fonte: Google imagens.

Ao observar as chamadas, vemos que os dois textos jornalísticos vão abordar a presença do Brasil em rankings internacionais. $\mathrm{O}$ atleta encontra-se em primeiro lugar no ranking enquanto os estudantes brasileiros figuram entre as últimas posições. Essa possível conexão entre as chamadas das duas reportagens pode ser ainda mais forte se 
levarmos em consideração a ausência de moldura entre elas, criando uma maior conexão entre esses dois elementos do texto multimodal. A união das duas permite ao/à leitor/a enxergar o aluno escrevendo na ponta dos pés, em um grande esforço no seu contexto de aprendizagem, enquanto, mais acima, é posicionada a medalha de ouro, talvez indicando um longo caminho ainda a ser percorrido para que nosso país também figure entre os primeiros colocados no tocante à avaliação de nosso sistema de ensino.

Além das cores, o próprio quadro escolar pode ser considerado um processo simbólico, uma vez que, na imagem em questão, vemos o uso do quadro com giz em vez de uma lousa e pincel atômico. Simbolicamente, o quadro de giz tradicional é talvez a primeira coisa que nos vem à mente quando pensamos na representação do contexto escolar, aqui ocupando a maior parte da capa e posicionado no centro, o lugar de maior destaque. O quadro de giz, em lugar do quadro branco, pode sugerir ao/à leitor/a ideia de atraso, de precariedade, de uma sala de aula sem muitos recursos, enquanto os erros ortográficos podem simbolizar as diversas falhas existentes nas instituições escolares.

Com relação à função interacional, temos questões relacionadas ao contato, atitude, distância social e poder. Sobre o contato, apesar de não termos acesso ao olhar do participante representado, podemos afirmar que ele está olhando para o quadro enquanto escreve a frase. Dessa forma, não há contato visual com o/a leitor/a, existindo apenas a oferta da mensagem escrita, o que pode indicar que a maior atenção do público deve ser voltada ao que está sendo escrito no quadro, e não a quem está escrevendo.

Da mesma maneira, ao falarmos de atitude, percebemos que há um nível máximo de não envolvimento entre o participante representado e o/a leitor/a, pois o participante está completamente de costas, contribuindo com a percepção de uma maior relevância da frase escrita e da imagem como um todo. No que diz respeito à distância social, temos uma representação em plano aberto (long shot), sugerindo certo grau de impessoalidade entre o participante e o/a leitor/a. Pelo ângulo e plano escolhidos, algo interessante de notar é que o/a leitor/a desse texto multimodal parece estar sendo posicionado como outro aluno dessa mesma sala de aula olhando para o quadro, de certa forma suavizando essa impessoalidade que a atitude parece sugerir. Isso também é reforçado pelo fato de que, ao falarmos de poder, observamos que o participante e o/a leitor/a se encontram no mesmo nível de olhar, indicando, assim, uma relação de igualdade de poder entre os dois, i.e., eles parecem compartilhar o mesmo contexto.

Com foco na função composicional, notamos que o quadro escolar e a frase nele escrita são os elementos mais salientes do texto multimodal. Como mencionado anteriormente, o quadro ocupa a maior parte da imagem, enquanto o seu posicionamento 
no centro da página, assim como o contraste, ajuda a atrair ainda mais a atenção do/a leitor/a. Perceba que a saliência não é medida apenas por um fator, mas resulta da interação entre vários deles como tamanho, cor, contraste, e nitidez. Com relação ao enquadramento, a ausência de moldura na parte superior da capa cria uma conexão entre as duas chamadas da revista, como já mencionado. Enquanto a presença de uma moldura criada pela margem inferior do quadro cria uma separação entre o que está escrito no quadro e abaixo dele, a existência de uma moldura enfraquece a conexão entre esses elementos. No entanto, nesse caso, ela evidencia a oposição entre eles, visto que, o que está escrito abaixo do quadro contradiz diretamente a frase escrita pelo aluno e vice-versa.

Quanto ao valor da informação, temos a disposição em topo e base, na qual o texto verbal no quadro e o texto na margem inferior dele sugerem respectivamente a informação ideal e a informação real. Nesse caso, o ideal a ser alcançado, conforme o texto verbal no quadro, é que o ensino no Brasil seja ótimo, ainda que a frase contenha vários erros de ortografia. Já a informação real, posicionada abaixo do quadro, afirma que os estudantes brasileiros estão entre os piores do mundo, e que mais de $90 \%$ dos pais e professores aprovam as escolas.

Observe que, apesar de não termos acesso ao resto da sala de aula na imagem, não parece haver problema estrutural explícito que pudesse representar alguma dificuldade ou obstáculo para o aprendizado. Dessa forma, entende-se que a sala de aula, a princípio, conta com o mínimo necessário para que os/as alunos/as possam experienciar situações adequadas de ensino-aprendizagem. Contudo, o uso incorreto do português pelo aluno, segundo a norma padrão, sugere, como estratégia discursiva, que isso não acontece, dando a entender que o problema parece não estar exatamente na estrutura física, mas, sim, em outro aspecto. Surge, então, possíveis questionamentos: Onde está o problema? Quem, ou qual, seria a causa do baixo desempenho dos/as alunos/as?

A publicação, de viés político conservador, usa o discurso presente no texto a fim de conduzir os/as leitores/as a um alinhamento com sua visão ideológica, pois, ao mostrar a incapacidade do aluno em escrever uma frase sem erros ortográficos, aliada à ironia contida na frase, o texto multimodal constrói uma representação negativa do ensino no Brasil, mais especificamente dos/as professores/as brasileiros/as. Tal representação destaca o papel constitutivo da linguagem (verbal e imagética) na sociedade, visto que, por meio do discurso multimodal, percebemos como os/as professores/as são representados/ as em uma mídia de grande alcance a partir da posição de poder que a revista Veja ocupa. São evidenciadas, assim práticas sociais particulares, por meio das quais se pretende 
atribuir culpa a indivíduos que não detêm o mesmo aparato sociopolítico e econômico para mostrar, em igual escala midiática, seu ponto de vista sobre a situação.

É importante observar que a matéria, publicada durante o mandato do presidente Luiz Inácio Lula da Silva, em nenhum momento, fez um questionamento ao/à leitor/a sobre quem é o responsável pela situação, mas afirma, de maneira categórica, tanto por meio da ironia contida na frase escrita pelo aluno, quanto por meio do texto abaixo do quadro, que "Os erros não são só dele", cabendo ao/à leitor/a tirar suas conclusões: Quais erros não são só dele? Os de ortografia na frase do quadro escolar? Ou existem outros erros que contribuem para que os/as estudantes brasileiros/as estejam, supostamente, entre os/as piores do mundo? E se não são só dele, de quem mais seriam esses erros? As respostas vêm ao longo do texto multimodal, com a afirmação de que $90 \%$ dos pais e professores/as aprovam a escola. Assim, a publicação lhes atribui parte da culpa, enquanto os/as coloca na posição de alienados/as, alheios/as à situação alegada de que o ensino no país é falho.

A revista afirma que as mães e os pais brasileiros/as de todas as classes sociais, com raríssimas exceções, não se envolvem como deveriam na vida escolar dos/as filhos/ as e que as consequências disso são um complexo educacional medíocre, com alunos/ as despreparados/as para o mundo atual. O editorial argumenta, ainda, que a avaliação positiva feita pelos pais e professores/as está equivocada, e que o otimismo com o desempenho do sistema precisa ser transformado em radical inconformismo para que a educação finalmente avance (WEINBERG; PEREIRA, 2008). O discurso do texto da publicação está marcado por questões ideológicas que buscam atender a interesses específicos de uma classe, nesse caso a oposição conservadora, parte significativa dos/as leitores/as da revista, que estava insatisfeita com os rumos da educação no país.

Ao virar a página, o/a leitor/a pode detectar rapidamente a que se propõe a matéria, pois, ao se deparar com a imagem de uma foice e um martelo, em alusão ao símbolo usado pelos partidos comunistas ao redor do mundo, percebe-se o discurso da revista contra a influência dessa ideologia na educação. Logo abaixo, lê-se o título em letras garrafais: "Prontos para o século XIX", pois, de acordo com o discurso da publicação, os/as alunos/as estão sendo preparados para viver no fim do século XIX, quando o marxismo surgiu como uma ideologia modernizante, capaz de mudar o mundo e acelerar a marcha da história rumo a uma sociedade sem classes. A matéria, porém, enfatiza que estamos no século XXI e que o comunismo destruiu a si próprio em miséria, assassinatos e injustiças durante suas experiências no século passado. Como destacado por Weinberg 
e Pereira (2008, p. 77), “é embaraçoso que o marxismo-leninismo sobreviva apenas em Cuba, na Coreia do Norte e nas salas de aula de escolas brasileiras".

Ao assinalar que os/as professores/as, tanto da rede pública como privada, doutrinam ideologicamente os/as estudantes em vez de ensiná-los/as matérias essenciais do currículo base, a reportagem evidencia o direcionamento editorial da Veja, assim como sua ideologia antimarxista, tanto por meio de marcas linguísticas já descritas, como na exploração de recursos de intertextualidade, ao se referir a pensadores como Karl Marx e Paulo Freire. Além de Weinberg e Pereira (2008) questionarem, de maneira explícita, a capacidade intelectual dos/as docentes ao afirmarem que não seriam capazes de ler Karl Marx por ser "autor rigoroso, complexo, profundo que, mesmo tendo apenas uma de suas ideias levada a sério hoje - A Teoria da Alienação -, exige muito esforço para ser compreendido" (p. 77), também acrescentam outros insultos a personalidades reconhecidas internacionalmente pela qualidade e importância de seu trabalho, como Paulo Freire, afirmando que ele não oferece "contribuição efetiva à civilização ocidental, (...), [sendo apenas] autor de um método de doutrinação esquerdista disfarçado de alfabetização" (p. 83).

Como já mencionado, o texto parece não deixar espaço para questionamentos. A interpretação generalizada da revista de que os/as professores/as são doutrinadores/as de esquerda é apresentada como verdade absoluta. Dessa maneira, ao criar tal representação da realidade, a reportagem a constrói como natural, de modo que essa naturalização contribui para silenciar outras realidades além daquela que a revista apresenta ao/à leitor/a para servir aos seus interesses particulares editorais e comerciais. É importante destacar que, ao analisarmos o texto multimodal da capa, percebemos que ele não é tão explícito no que concerne às críticas encontradas na reportagem no interior da revista. Dessa maneira, para compreender que a publicação aponta o/a professor/a como um/a dos/as responsáveis pelo fracasso da educação no país, é preciso analisar elementos macrotextuais, que são identificáveis ao se fazer a leitura da matéria correspondente.

Assim, fica evidente que a publicação procura atrair a atenção do/a leitor/a para essa questão ao implicar que a educação no Brasil é péssima e que os sujeitos envolvidos não estão conscientes disso, fazendo com que os/as leitores/as acreditem que precisam ler a matéria a fim de encontrar as informações e descobrir as raízes desse problema. Nesse sentido, é possível afirmar que o texto multimodal da capa e o texto encontrado na reportagem no interior da revista refletem desejo de deslegitimar o papel de parte dos/as professores/as no país, invalidando seus discursos e seu trabalho, além de imputar-lhes a culpa pela má qualidade do sistema educacional. 
Da mesma forma, reflete o desejo de manutenção da posição hegemônica pela classe dominante, que teme que a educação seja influenciada pelos ideais da esquerda supostamente levados e impostos aos/às alunos/as, podendo representar uma ameaça à posição socioeconômica conquistada por eles a partir do questionamento de parte da população sobre o status quo que lhe permite tal manutenção.

\section{Revista Carta Capital}

A revista Carta Capital, fundada em São Paulo em agosto de 1994 por Mino Carta (um dos criadores da revista Veja), Bob Fernandes, Nelson Letaif e Wagner Carelli, iniciou suas publicações com periodicidade mensal, passando a ser quinzenal em 1996, e semanal em 2001. Publicada pela editora Confiança, tem conquistado, apesar de uma tiragem consideravelmente menor que aquela da revista Veja, notável importância nacional pela sua atuação crítica em relação à imprensa hegemônica e por declarar sua posição política em seu editorial em seu mídia kit.

Há 26 anos CartaCapital é a única semanal a oferecer um contraponto ao pensamento único, totalizante, empobrecedor. Acreditamos de forma inabalável no poder do jornalismo crítico e analítico como remédio para um Brasil dividido e enfraquecido. Em tempos de falso moralismo, exaltamos o plural e o diverso. Em qualquer tempo respeitamos a inteligência dos leitores. Nosso compromisso é com um país mais moderno e justo. Todos os dias. Ainda que os tempos sejam duros. Acreditamos que uma sociedade é tão mais desenvolvida quanto maior a presença e pluralidade de vozes. Por isso reunimos em nosso time de colunistas uma série de figuras importantes nas mais diversas áreas e que nos ajudam a fomentar o debate sobre diferentes assuntos. Além de seu time de colunistas, CartaCapital possui uma rede de parceiros composta por vozes que nos ajudam a disseminar nosso discurso progressista e em prol de uma sociedade mais justa, igualitária e democrática. ${ }^{4}$

A revista, disponível nos formatos impresso e digital, aborda principalmente três temas: política, economia e cultura. De acordo com os dados disponibilizados em seu mídia kit, a sua tiragem média foi de 26.500 exemplares em 2019. Segundo esses dados, o perfil dos consumidores da Carta Capital é, em grande maioria, formado por pessoas do sexo masculino nas faixas etárias 18-24 anos e 25-34 anos.

\footnotetext{
${ }^{4}$ CARTA CAPITAL. Midia kit: Carta Capital. Disponível em: https://www.cartacapital.com.br/ wp-content/uploads/2020/06/midia_kit2020.pdf. Acesso em: 09 jun. 2020.
} 
Diferentemente da revista Veja, a Carta Capital não disponibilizou dados sobre o perfil socioeconômico dos seus assinantes, apenas o perfil demográfico, por meio do qual percebemos que, assim como a própria publicação, que é mais recente em relação às outras duas revistas, o seu público principal também é mais jovem. A imagem (Fig. 15) traz um alvo do tipo silhueta, desenhado de giz em um quadro escolar, onde, no lado esquerdo, lê-se: "O professor é o alvo, mas o tiro sai pela culatra".

Figura 15: Capa da Revista Carta Capital (ed. 1055 de 2019).

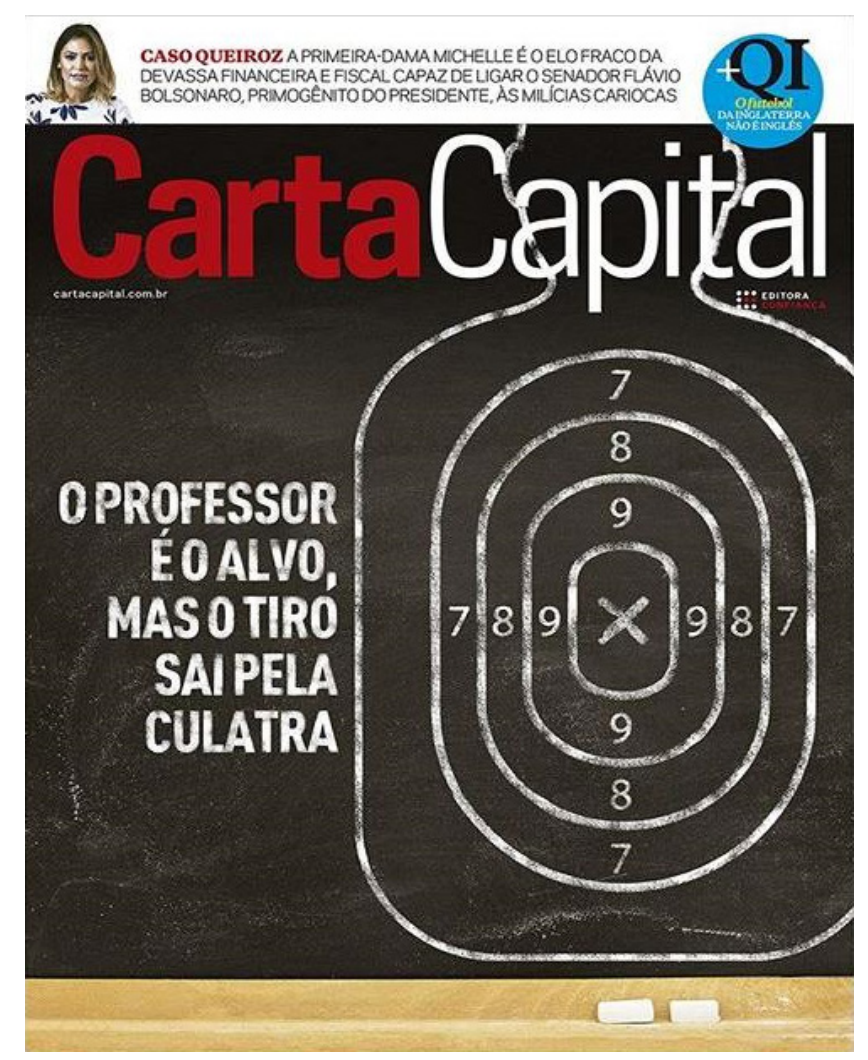

Fonte: Google imagens.

Ao analisarmos esse texto multimodal a partir da função representacional, podemos afirmar que se trata de uma representação conceitual com processo simbólico atributivo, visto que não há qualquer vetor que sinalize uma ação sendo executada. Além disso, apesar de não haver participante humano/a representado/a na imagem, o alvo do tipo silhueta indica características humanas, evidenciando, assim, o processo simbólico. Não é possível ver se existe alguém mirando no alvo, porém, pelo plano e ângulo da imagem, o/a leitor/a é posicionado/a como possível atirador/a. 
Podemos inferir, então, que um tiro, não representado na imagem, potencialmente atingiria o alvo, inferência ratificada pela leitura do texto verbal, no qual a frase "o professor é o alvo, mas o tiro sai pela culatra" ajuda o/a leitor/a compreender que o alvo desenhado com giz no quadro escolar simboliza a figura do/a professor/a. Ao dizer que "o tiro sai pela culatra", a chamada da matéria implica que algo não saiu como planejado, sugerindo que escolher o/a professor/a como alvo poderá trazer consequências contrárias às esperadas por quem o/a colocou nessa posição.

Sobre a função interacional, é difícil identificar contato e atitude, já que não é possível distinguir se a silhueta simboliza o/a professor/a de frente ou de costas, por não existir nada que remeta a um rosto, motivo pelo qual não temos acesso à direção do olhar. Ao falar da distância social, vemos que se trata de um plano médio (medium shot), dando a ideia de um vínculo social entre o/a participante e o/a leitor/a, ou seja, a relação é meramente social, sugerindo que não existe intimidade entre eles. E quanto ao poder, o/a participante simbolizado/a no texto multimodal está no mesmo ângulo de câmera do/a leitor/a, sugerindo relação de igualdade de poder entre os dois. No entanto, essa relação de igualdade seria apenas ilusória, uma vez que, neste tipo de situação, o alvo se encontra em uma posição de inferioridade e vulnerabilidade em relação ao/à atirador/a.

Em termos composicionais, ao analisarmos o valor das informações dispostas no texto multimodal, vemos que a informação conhecida, posicionada do lado esquerdo, seria o texto verbal "O professor é o alvo, mas o tiro sai pela culatra". Essa informação já é conhecida pelos leitores da revista, uma vez que as manifestações contra os cortes na educação era o assunto mais repercutido pela mídia na ocasião do lançamento da referida edição, e os/as professores/as encontravam-se no centro da discussão. Isto posto, a informação nova seria a imagem do alvo no quadro escolar, ocupando o lado direito da composição e apresentado como representação da figura do/a professor/a, de modo a ilustrar o que foi dito no texto verbal e alcançar seu objetivo de atrair imediatamente a atenção do/a leitor/a para a chamada da matéria e, posteriormente, a sua leitura na íntegra.

Além disso, sobre o enquadramento, não notamos moldura destacada, mas observamos que a imagem está enquadrando apenas uma parte do quadro escolar, deixando o alvo bem mais próximo ao/à leitor/a, uma vez que, na prática de tiro ao alvo, é necessário que exista uma certa distância entre atirador/a e alvo, tornando este mais difícil e cumprindo o propósito de exercitar a mira. Nesse sentido, identificamos também o uso de saliência enfatizando o texto multimodal, destacando o alvo silhueta e a borda de madeira na parte inferior do quadro escolar, além dos pedaços de giz (podendo simbolizar cartuchos de bala), que reforçam a composição sem deixar dúvidas sobre o 
contexto de uma sala de aula. Quanto à modalidade, podemos considerá-la alta, tendo em vista a possibilidade de identificarmos as texturas do quadro e da borda de madeira, além do quadro manchado de giz, detalhes que aumentam o grau de realismo da imagem, sugerindo a seriedade com que o tema será abordado.

A partir de uma linha editorial definida, a Carta Capital destaca sua posição política alinhada a um discurso progressista. Exemplos disso são os apoios abertos ao candidato Luiz Inácio Lula da Silva (PT) nas eleições presidenciais de 2002, em sua edição n ${ }^{\circ} 209$, e à candidata Dilma Rousseff, nas disputas eleitorais de 2010, em sua edição $n^{0}$ 603. Dessa forma, assim como acontece com a revista Veja, a Carta Capital tem um público que se identifica com a sua linha editorial em contradiscurso às posições frequentes da mídia impressa hegemônica. Vemos, assim, que, com base na ideologia daqueles que controlam um veículo informativo, estabelece-se sua linha editorial que condiciona que tipo de informação será divulgada, de que maneira o será e quem terá voz no veículo (BARREIROS; AMOROSO, 2008).

A reportagem da capa aqui analisada, intitulada "A revolta das letras" escrita por Rodrigo Martins, confirma o que foi relatado na análise multimodal. Ao colocar o/a professor/a no alvo, o tiro do governo saiu pela culatra, trazendo consequências como as manifestações discutidas na reportagem principal da revista. Em maio de 2019, ocorreram protestos e paralisações em todos os estados brasileiros e no Distrito Federal, tendo tido como principal motivo a decisão do Ministério da Educação (MEC) de bloquear 24,84\% dos gastos não obrigatórios dos orçamentos das instituições federais. Tais despesas incluíam contas de água, luz e compra de material básico, além de financiamento de pesquisas. Apoiadores do governo atacavam os/as professores/as e as universidades públicas, e uma fala do então ministro da Educação Abraham Weintraub aqueceu ainda mais as discussões. Em entrevista ao jornal "O Estado de São Paulo" em 30 de abril de 2019, o ministro sinalizou cortes em universidades onde houvesse "balbúrdia", em combate a sum suposto "marxismo cultural". Direcionando os cortes, inicialmente, a apenas três universidades (UnB, UFF e UFBA), decidiu, posteriormente, ampliar a ação para todas as instituições federais de ensino superior (IFES), bloqueando $30 \%$ de seus recursos (MARTINS, 2019).

Podemos verificar que a revista se posiciona de forma crítica em relação ao governo do atual presidente Jair Messias Bolsonaro, particularmente sobre suas decisões quanto à educação do país. Observa-se que, com os cortes na educação e as constantes críticas aos/às professores/as e às instituições federais, o governo causou a revolta de alunos/as e professores/as que ocuparam as ruas do Brasil para se manifestarem a favor 
da educação pública. Foi a primeira grande onda de manifestações contra o governo de Bolsonaro, pouco mais de quatro meses após ele ter tomado posse.

Em Dallas (EUA), em entrevista, o presidente classificou os/as manifestantes de "idiotas úteis" e "imbecis", acrescentando que: "A maioria ali é militante. Não tem nada na cabeça. Se perguntar quanto é 7 vezes 8 , não sabe. Se perguntar a fórmula da água, não sabe. Não sabe nada". A crítica ao governo é bem evidente na reportagem em questão, ao buscar o convencimento dos/as leitores/as por meio da exposição dos acontecimentos de maneira opinativa, utilizando-se de adjetivos negativos e comentários irônicos, relembrando falas e atitudes polêmicas atribuídas a Bolsonaro e seus ministros.

No entanto, enfatizando elementos e fatos históricos, a revista parece se diferenciar positivamente ao reforçar a ideia de credibilidade e de legitimidade da informação. Nesse sentido, temos como exemplo o seguinte trecho:

Convocado a prestar esclarecimentos à Câmara dos Deputados, Weintraub tentou se esquivar. "Não somos responsáveis pelo contingenciamento, o orçamento atual foi feito pelo governo eleito de Dilma Rousseff e [Michel] Temer, que era vice". Mentira. O orçamento foi aprovado pelo Congresso e apresentado por Temer em 2018, dois anos após a destituição de Dilma por um golpe parlamentar. (MARTINS, 2019, s/p)

Segundo a reportagem, o governo faz uso de fake news em sua guerra ideológica, na qual o/a professor/a é visto/a como um obstáculo, um/a inimigo/a que deve ser combatido/a. Percebe-se, assim, que a Carta Capital parece evidenciar práticas discursivas e sociais que criam representações dos/as professores/as por um viés mais atento à complexidade das experiências particulares em um complexo sistema educacional. Mais uma vez, podemos remeter essa afirmação à análise do texto multimodal da capa da publicação, "o tiro sai pela culatra”, visto que Bolsonaro não esperava que os ataques do seu governo aos/às professores/as e universidades fossem causar tamanha repercussão. Nesse sentido, podemos sugerir que o alvo silhueta representa o/a professor/a, e que o/a professor/a representa a educação superior brasileira na mira do governo.

Ainda, de acordo com a matéria de Carta Capital, Bolsonaro mentiu ao dizer que as universidades federais produzem pouca pesquisa, ao contrário das instituições privadas. Martins (2019) explica que, na realidade, acontecia justamente o oposto, pois, segundo o relatório Research in Brazil, produzido pela Clarivate Analytics para a CAPES, quase a totalidade do conhecimento científico produzido no país entre 2011 e 
2016 vem de universidades públicas e gratuitas, posicionando-as na liderança absoluta do ranking das mais produtivas e bem-conceituadas.

Outro ponto levantado pela publicação é a preocupante ameaça, por parte do governo federal, de fechar cursos de Filosofia e Sociologia, incentivando alunos/ as a filmar os/as professores/as em sala de aula, com o objetivo de acusá-los/as de "doutrinação", e ainda pressionando editoras de livros didáticos a reescrevê-los, omitindo termos como "ditadura" e conteúdos sobre gênero e diversidade (MARTINS, 2019). Esses movimentos discursivos, ao utilizarem elementos linguísticos particulares (p. ex. doutrinação, ditadura, marxismo, ideologia de gênero, etc.), e ao acionarem relações intertextuais e interdiscursivas com autores/as largamente desconhecidos por significativa parte da população, contribuem para a criação (e manipulação) de um imaginário popular contrário a seus próprios interesses, que, eventualmente, apenas fortalecem as relações de poder dominantes já existentes.

Sendo assim, pode-se dizer que o governo incentiva uma relação hostil no contexto educacional, uma vez que estimula os/as alunos/as a filmarem professores/as quando estiverem "doutrinando" - quando, na verdade, essa relação tão importante entre professores/as e alunos/as deveria ser entendida e defendida a partir de sua inescapável natureza dialógica. A despeito da liberdade de cátedra, sob essa ótica, os/as professores/ as estariam sujeitos/as ao arbítrio dos/as alunos/as, tudo a fim de evitar a disseminação do pensamento político ideológico que diverge do proposto pelas classes políticas e econômicas dominantes.

Ademais, o pensamento hegemônico, por ser a ideia dominante dos espaços discursivos, é normalizado e, consequentemente, menos notado pelos indivíduos da sociedade. De maneira oposta, o pensamento não hegemônico, isto é, aquele que diverge da ideia dominante, torna-se mais evidente, claro e impactante, uma vez que ameaça o status quo. Por conta disso, a ideia não hegemônica impacta o espaço discursivo, tornando-se falsamente a única proposta ideológica, quando, na verdade, ambas posições políticas discutidas acima, diametralmente opostas entre si, não poderiam ser outra coisa senão ideológicas.

Os discursos produzidos pela revista Carta Capital são vistos como doutrinários por boa parte da classe dominante, que tem seu representante como chefe do governo, pois visam uma mudança no paradigma e contradizem as verdades consagradas pelos meios hegemônicos. Enquanto isso, a revista acusa Bolsonaro e seu governo de travar uma guerra ideológica contra os/as professores/as e usar os cortes orçamentários para atacá-los/as e acusá-los/as de disseminar o "marxismo cultural". 
Em reportagem de maio de 2019 do site de notícias El País, a jornalista Naiara Galarraga Gortázar afirma que Jair Bolsonaro nunca escondeu que considera as universidades públicas um ninho de vermelhos perigosos, e a qualidade da educação, desastrosa. Erradicar o que denomina de "marxismo cultural" e "ideologia de gênero" das salas de aula é uma de suas obsessões (GORTÁZAR, 2019). Portanto, a decisão do governo de criticar, ou até mesmo atacar, os/as professores/as e as universidades públicas trouxe consequências, visto que as investidas do governo contra os/as docentes contribuíram para desgastar ainda mais a imagem do presidente Jair Bolsonaro, que conta com a menor aprovação no início de um primeiro mandato desde o fim da ditadura (MARTINS, 2019).

\section{Revista Nova Escola}

A Nova Escola, criada em 1986 pela Fundação Victor Civita, foi destinada especialmente aos/às professores/as da rede básica de ensino. Em sua primeira edição, a revista, "resultado de um velho sonho e de um longo trabalho de uma equipe de experimentados jornalistas e profissionais da Educação", apresentou como seu principal objetivo "fornecer à professora informações necessárias a um melhor desempenho do seu trabalho" (FUNDAÇÃO, 1986, p. 5).

Na mesma edição, o presidente Victor Civita afirmou que o lançamento da revista teve grande apoio de empresas privadas e que seu principal objetivo era contribuir para a melhoria do ensino fundamental, divulgando informações que contribuam diretamente para a formação e o aperfeiçoamento profissional dos/as professores/as. A revista é a de maior circulação no âmbito educacional, possibilitando, devido a uma parceria com o Ministério da Educação, ampla divulgação da mesma em escolas públicas de todo território nacional. Hoje, são mais de 415.000 periódicos impressos.

De acordo com o mídia kit ${ }^{5}$ disponível no site da Nova Escola, a revista tem uma tiragem média de 20 mil exemplares, com periodicidade mensal, contudo com apenas dez edições por ano, visto que nos meses de férias escolares a revista não é publicada. Sobre o perfil dos leitores da versão impressa da revista, a publicação conta com $78 \%$ do seu público do sexo feminino; 67\% estão na faixa etária de 20 a 49 anos; $69 \%$ pertence às classes B e C; 76\% são professores; e 32\% são gestores escolares. Ademais, o perfil do

\footnotetext{
${ }^{5}$ NOVA ESCOLA. Mídia Kit. Nova Escola, 2019. Disponível em: https://novaescola.org.br/ assets/img/pdf-parcerias/NOVAESCOLA_TabelaMidiaKit2019.pdf. Acesso em: 10 jun. 2020. 
usuário da plataforma online da Nova Escola é formado por $80 \%$ de mulheres; $67 \%$ na faixa etária de 25 a 59 anos; e $80 \%$ são professores/as da educação básica.

A Nova Escola se autointitula a maior plataforma de produtos e serviços para educadores do Brasil, contando com mais de 6 mil planos de aulas disponíveis para os professores, além de 13 guias práticos alinhados à Base Nacional Comum Curricular (BNCC). Dessa forma, a Nova Escola passou de revista impressa a plataforma educacional com diversos recursos pedagógicos, assim como produtos e serviços voltados para educadores. A última capa a ser analisada (Fig. 16) mostra a imagem de uma professora e, ao redor desta, as seguintes frases: "Estamos endividados"; "Pagamos para trabalhar"; "Nossos contratos são ruins"; "Fazemos trabalhos extras para sobreviver"; e "Somos professores e queremos respeito". Além das frases ao redor do rosto da professora, do lado esquerdo temos a chamada principal da revista "O Brasil não paga o que eles merecem", e, do lado direito, lê-se: "A professora Márcia de Manaus vende roupas e faz serviços gerais para pagar as contas".

Figura 16: Capa da Revista Nova Escola (ed. 318 de 2019).

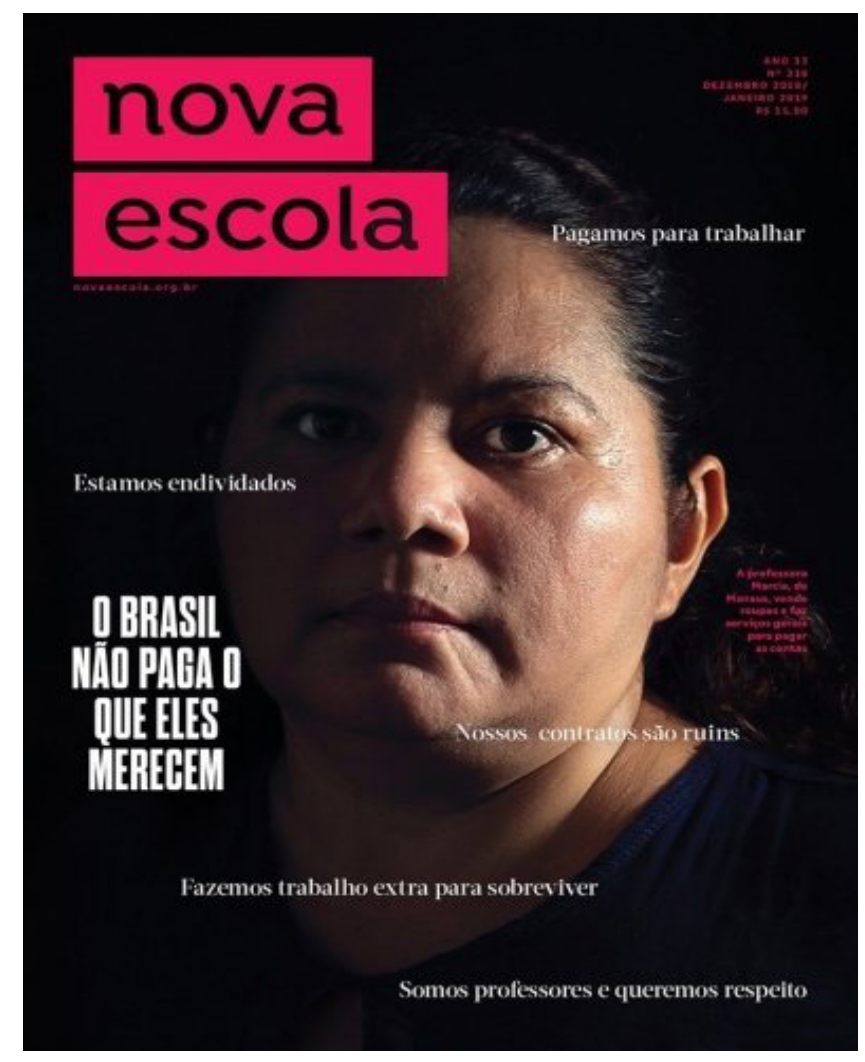

Fonte: Google imagens. 
Quanto à análise desse texto multimodal, em termos representacionais, podemos perceber que os sentidos conceituais ocupam maior destaque, por meio de um processo analítico, pois a professora é representada apenas pelo seu rosto, em close-up, sugerindo que a atenção do/a leitor/a deve ser voltada à expressão facial séria da participante, juntamente com as sombras no seu rosto e, consequentemente, os possíveis sentidos criados com isso.

Podemos ver todos os detalhes do seu rosto, como se ela estivesse a poucos centímetros do/a leitor/a, sugerindo intimidade entre eles. Também podemos falar em um processo simbólico sugestivo, pois as frases espalhadas ao redor da professora representada na imagem também simbolizam as vozes dos demais professores insatisfeitos, que, apesar de não estarem explicitamente representados na capa, estão no interior da revista, na matéria a que ela se refere.

Ainda sobre os processos simbólicos, vemos a professora em um pano de fundo escuro, onde apenas parte do seu rosto é iluminado, dando uma ideia de dualidade, possivelmente remetendo à vida dupla ou jornada dupla de trabalho que ela precisa ter para sobreviver, de dia como professora e à noite como auxiliar de serviços gerais. Além disso, o fato de a professora ser representada em meio às sombras, alude à ideia de que ela está à margem, na escuridão, reforçando o sentido de que sua profissão é desvalorizada.

Em relação à função interativa, temos o contato identificado por meio do olhar da participante representada, que olha diretamente para o/a leitor/a, indicando demanda. A expressão no rosto da professora sugere frustração, decepção e até mesmo tristeza. O seu olhar provavelmente demanda atenção à sua história, e chama o/a leitor/a para a leitura da matéria a fim de conhecer a realidade dela e de outros/as professores/as em situação semelhante. Sobre a distância social, notamos o plano fechado (close-up) que acentua ainda mais o chamamento ao/à leitor/a, sugerindo uma relação de intimidade imaginária com este(a), pois, ainda que eles não se conheçam, a participante vai compartilhar detalhes de sua vida como faria com alguém próximo a si.

No mesmo sentido, quanto à atitude, temos o ângulo frontal demonstrando alto grau de envolvimento entre a participante e o/a leitor/a. Ainda reforçando as ideias apresentadas por meio das categorias de análise anteriores, temos o ângulo médio da foto, com a participante no mesmo nível de olhar do/a leitor/a, indicando relação de igualdade de poder entre eles, que pode sugerir um maior grau de empatia entre os participantes.

Ao tratar dos elementos composicionais no texto multimodal, observamos, sobre o enquadramento, que não há moldura, sendo, dessa forma, possível afirmar que a ausência de fundo contribui para que o rosto da professora, mais precisamente seu 
olhar e sua expressão facial fiquem em evidência, atraindo a atenção do/a leitor/a para o que eles representam. Diferentemente da capa anterior, aqui vemos a saliência sendo usada como meio de enfatizar e destacar a participante representada por meio das cores, sombras e posicionamentos.

É interessante mencionar que o texto verbal foi disposto ao redor da professora, com ela no centro, e as frases em primeiro plano, como se estivessem "coladas" como etiquetas, enquanto a ausência de molduras nos sugere uma alta conexão entre elas e a participante representada. Tal disposição confere destacada importância ao texto verbal, pois representa as vozes dos/as demais profissionais de uma mesma classe (professores/as brasileiros/as), que estão na capa representados/as pela professora Marcia Regina da Silva Santos.

É possível notar que essa matéria parece ter sido, no escopo deste estudo, aquela que adotou uma postura menos partidária, enfatizando o depoimento da professora representada no texto multimodal, como crítica à realidade de grande parte desses/as profissionais no Brasil. Não afirmamos, contudo, que essa constatação implica neutralidade da professora e/ou da revista, pois somos todos/as evidentemente atravessados/as por ideologias e vivências particulares, que impactam a representação da realidade da maneira como a percebemos. O texto da reportagem, apesar de curto, revela, para os/as leitores/as, os desafios enfrentados pela professora para sobreviver e para exercer sua profissão. No trecho abaixo, por exemplo, a professora compartilha um pouco de sua experiência:

\footnotetext{
Nasci no interior do Amazonas, em Nhamundá. Hoje, moro na capital. Todos os dias acordo às 4 horas da manhã e atravesso Manaus para ir para Iranduba, onde trabalho como professora na comunidade ribeirinha Lago do Catalão, na escola flutuante Nossa Senhora Aparecida. Para chegar lá, preciso primeiro ir de ônibus e depois atravessar o Rio Negro de lancha. Levo duas horas para ir mais duas horas para voltar. Só consigo chegar porque eu e meus colegas professores pagamos o atravessador, que também vive na comunidade. A aula vai das 7 às 11 horas. À tarde, já em Manaus, vendo roupas e bijuterias para complementar a renda e, à noite, trabalho em outra escola próxima da minha casa. (ANNUNCIATO; OLIVEIRA, 2019, s/p)
}

A publicação dá voz à professora Marcia Regina, que tinha seu sofrimento e história invisibilizados aos olhos da sociedade. Quando voltamos ao texto multimodal, percebemos que a imagem demonstra justamente esse fato, visto que a participante está representada na escuridão, cabendo à revista direcionar um pouco de luz para iluminar 
parte de sua realidade diária, antes escondida em meio aos outros ofícios que ela precisava realizar para conseguir seu sustento e de sua família.

Sendo assim, apesar de seus conteúdos serem principalmente voltados para a Educação Infantil e o Ensino Fundamental, com práticas de ensino e assuntos que dizem respeito ao cotidiano escolar, suas edições também contam com relatos de experiências e entrevistas com os professores. Portanto, podemos dizer que o discurso produzido pela capa da revista Nova Escola analisada parece ser não hegemônico, ao evidenciar o/a professor/a negligenciado/a e esquecido/a pelo Estado e pela sociedade. Assim, mesmo que de maneira indireta e sem responsabilizar terceiros, a revista produz contradiscursos que podem influenciar positivamente os/as leitores/as ao dar voz a profissionais invisibilizados/as, como a professora Marcia Regina.

\section{CONSIDERAÇÕES FINAIS}

Ao longo da presente pesquisa, levantou-se o questionamento sobre como representações dos/as professores/as foram construídas pelas revistas nacionais. Sob esse panorama, foram analisadas as revistas Veja, Carta Capital e Nova Escola, quando foi possível perceber como a integração entre o texto verbal e a imagem criou significados e identidades, revelando o teor ideológico presente nos textos multimodais das publicações.

A primeira revista analisada foi a Veja, que escolheu representar o/a professor/a negativamente, responsabilizando-o/a pelo péssimo resultado dos/as alunos/as brasileiros/as em um ranking internacional de educação. Além disso, acusou aqueles/ as de doutrinação ideológica, tendo sido verificados mecanismos linguísticos utilizados para gerar um demérito aos/às professores/as, generalizando-os/as e chamando atenção dos/as leitores/as para a necessidade de vigiar o que está sendo ensinado na sala de aula como forma de evitar o que a publicação chama de esquerdização dos/as estudantes.

Em contrapartida, a revista Carta Capital escolheu mostrar o/a professor/a na posição de vítima, uma vez que, logo de início, pode-se notar, em sua capa, a imagem do alvo representando o/a professor/a na mira do governo. Nesse sentido, em relação à Veja, houve uma mudança no perfil ideológico quando da análise do texto multimodal. Percebe-se destaque evidente a uma relação de hostilidade por parte do governo federal ao estimular visões de que os/as professores/as são doutrinadores/as, bem como quando ameaça e, posteriormente, efetiva cortes orçamentários que impactam todo o sistema educacional.

A revista Nova Escola, por sua vez, escolheu representar a figura do/a professor/a por meio de um caso individual, em que apresenta uma professora sobrecarregada e Revista X, v. 16, n. 3, p. 742-772, 2021. 
desvalorizada, que precisa se desdobrar em três empregos para conseguir o seu sustento e de sua família. Essa representação é feita, particularmente, pelo foco no discurso não hegemônico da própria professora, que, ao falar sobre suas vivências, visibiliza para os/ as leitores/as situações que, não raro, são desconhecidas por grande parte da população.

Com base nessas análises, foi possível compreender que os elementos imagéticos e verbais das revistas têm potencial de influenciar consideravelmente a leitura da imagem dos/as professores/as, informando, de maneira significativa, o imaginário coletivo sobre esses/as profissionais, sua profissão, e a relação que estabelecem com organização socioeconômica e política do país. Nessa lógica, concluiu-se que os textos multimodais são ferramentas poderosas para criar significados e construir visões da realidade, visto que tais textos estão imbuídos de discursos ideológicos que parecem (des)favorecer certas práticas, visões de mundo e identidades.

Diante disso, destacamos a importância de práticas de letramentos críticos, pois, para ser um membro mais consciente e proativo na sociedade contemporânea, é necessário desenvolvermos a capacidade de ler criticamente os textos multimodais que nos cercam no dia a dia, especialmente os textos produzidos pelos veículos midiáticos. Percebe-se, portanto, que o poder de manipulação da mídia pode atuar como forma de controle social, contribuindo para um processo de massificação de opiniões e de visões de mundo na sociedade, resultando num contingente de pessoas que acabam sendo alvo fácil de lideranças mal intencionadas nos diversos espaços da teia social, especialmente na âmbitos político, econômico e midiático.

\section{REFERÊNCIAS}

ANNUNCIATO P.; OLIVEIRA, T. De manhã sou professora. À noite faço serviços gerais. Nova Escola, São Paulo: Fundação Victor Civita, ano 33, n. 318, janeiro de 2019. Disponível em: https://novaescola.org.br/conteudo/13862/de-manha-sou-professora-anoite-faco-servicos-gerais. Acesso em: 17 maio 2020.

BARREIROS, T. E.; AMOROSO, D. Jornalismo estrábico: Veja e Carta Capital na cobertura do "escândalo do mensalão". Perspectivas de la Comunicación, Temuco, 2008. Disponível em: http://revistas.ufro.cl/ojs/index.php/perspectivas/article/view/16. Acesso em: 05 jun. 2020.

BEZERRA, F. A análise crítica do discurso e os multiletramentos: o papel da linguagem no fazer docente contemporâneo. In: NÓBREGA, Carmem; ARCOVERDE, Rossana; BRANCO, Sinara; FARIAS, Washington (org.) Educação linguística e literária: discursos, políticas e práticas. Campina Grande: UFCG, 2016. p. 189-204. 
BEZERRA, F.; FAGUNDES, J. Leitura crítica do discurso multimodal em representações midiáticas das manifestações de junho de 2013. Cadernos de Linguagem \& Sociedade, v. 19, n. 2, p. 95-114, 2018.

BEZERRA, F.; ROCHA, A. Investigando representações de masculinidades em capas de revistas para o público LGBT+. Revista do GELNE, v. 22, n. 1, p. 215-230, 2020.

COPE, B.; KALANTZIS, M. The things you do to know: an introduction to the pedagogy of multiliteracies. In: COPE, B.; KALANTZIS, M. (org.) A pedagogy of multiliteracies: learning by design. Hampshire, Nova York: Macmillan, 2015. p. 1-36.

FAIRCLOUGH, N. Language and power. 3 ed. Londres, Nova York: Longman, 2015[1989].

FAIRCLOUGH, N. Discourse and social change. Londres: Longman, 1992.

FREIRE, P. Ação cultural para a liberdade e outros escritos. Rio de Janeiro: Paz e Terra, 1984.

FUNDAÇÃO Victor Civita, Nova Escola, São Paulo, ano I, n 1, março de 1986, p. 5.

GORTÁZAR, N. G. Cortes e ataques às universidades públicas catalisam mobilização contra Bolsonaro, El País, São Paulo, 14 de maio de 2019. Disponível em: https://brasil. elpais.com/brasil/2019/05/11/politica/1557603454_146732.html. Acesso em: 18 jun. 2020.

HEBERLE, V. Multimodal literacy for teenage EFL students. Cadernos de Letras UFRJ, Rio de Janeiro, v. 27, p. 101-116, 2010.

IVC - Instituto Verificador de Comunicação. Auditorias. 2019. Disponível em: https:// ivcbrasil.org.br/\#/auditorias. Acesso em: 02 out. 2020.

KELLNER, D. Media culture: cultural studies, identity and politics between the modern and the postmodern. Londres, Nova York: Routledge, 2003.

KRESS, G.; VAN LEEUWEN, T. Reading images: the grammar of visual design. Londres, Nova York: Routledge, 2006.

MARTINS, R. A revolta das letras. Carta Capital, São Paulo, ano 19, n. 1055, 22 maio 2019. 
MEURER, J. Gêneros textuais na análise crítica de Fairclough. In: MEURER, J.; BONINI, A.; MOTTA-ROTH, D. (org.) Gêneros: teorias, métodos, debates. São Paulo: Ed. Parábola Editorial, 2005. p. 81-106.

NASCIMENTO, R.; BEZERRA, F.; HEBERLE, V. Multiletramentos: iniciação à análise de imagens. Linguagem \& Ensino, v. 14, n. 2, p. 529-552, 2011.

NLG - New London Group. A pedagogy of multiliteracies: designing social futures. In: COPE, B.; KALANTZIS, M. (org.) Multiliteracies: literacy learning and the design of social futures. Londres: Routledge, 2000[1996]. p. 9-36.

ROJO, R. Pedagogia dos multiletramentos: diversidade cultural e de linguagens na escola. In: ROJO, R; MOURA, E. (org.) Multiletramentos na escola. São Paulo: Parábola Editorial, 2012. p. 11-32.

ROYCE, T. Multimodal communicative competence in second language contexts. In: ROYCE, T; BOWCHER, Wendy (org.) New directions in the analysis of multimodal discourse. Mahwah: Lawrence Erlbaum, 2007. p. 361-403.

VAN LEEUWEN, T. Introducing social semiotics. Londres, Nova York: Routledge, 2005.

WEINBERG, M.; PEREIRA, C. Você sabe o que estão ensinando a ele? VEJA, São Paulo: Abril, Edição 2074, Ano 41, n. 33, 20 de agosto de 2008. 